\title{
Prospects of Further Evolution of Culturology
}

\author{
Anna Iosifovna Scherbakova, ${ }^{1}$ Larisa Sergeevna Zorilova, ${ }^{2}$ Natalia Ivanovna \\ Anufrieva, ${ }^{3}$ Alexander Vladlenovich Kamenets, ${ }^{4}$ Elizaveta Olegovna \\ Zinchenko ${ }^{5}$ \\ ${ }^{1}$ Professor, Head of Department Professor of sociology and philosophy of culture, Russian State Social \\ University, Russia, 129226, Moscow, Vilgelma Pika st., 4, 1, Email: WerbakovaAl@rgsu.net. \\ ${ }^{2}$ Professor, Dean of the Faculty of Musical Arts, Moscow State Institute of Culture, 141406, Moscow \\ region, Khimki city, Bibliotechnaya str., 7,Email: zorilova@mail.ru. \\ ${ }^{3}$ Professor, acting Dean of Faculty of Arts and Cultural activities, Russian State Social University, Russia, \\ 129226, Moscow, Vilgelm Pik st., 4, 1, Email: nata415485@mail.ru. \\ ${ }^{4}$ Professor, Department of Sociology and Philosophy of Culture, Russian State Social University, Russia, \\ 129226, Moscow, Vilgelm Pik st., 4, 1, Email: kamenez.a@rambler.ru. \\ ${ }^{5}$ Senior Lecturer, Department of Sociology and Philosophy of Culture, Russian State Social University, \\ Russia, 129226, Moscow, Vilgelm Pik st., 4, 1, Email: najniv_almira@mail.ru.
}

Received May 22, 2016; Revised July 10, 2016; Accepted July 10, 2016; Published August 18, 2016

\begin{abstract}
The article deals with the definition of subject matter and scientific status of culturology. It provides comparative analysis of cultural studies at home and abroad and traces back scientific evolution of culturology as well as of sociocultural anthropology which is a more broadly used notion in foreign studies. Highlighting the main modern doctrines and historical theoretic foundations of culture studies the paper focuses on contribution of Leslie White who articulated key research problems of culturology. His innovative conception of cultural science and its further evolution was later embraced by Russian school of culturology. Recognizing high potential of Russian national culture as substance for further cultural studies the article outlines potential ways of formation of culturology in Russia and tries to find its place in the global context while maintaining traditions of studying culture as a social phenomenon. Cultural values, its spiritual and moral foundations which appear to be ignored by related social sciences are put forward as one of the main research subjects. Analysis of differences in Russian and Western approaches to substance and essence of cultural studies stresses the need to specify scientific perception of culturology by modern scholars.
\end{abstract}

Key words: culture, science, spirituality, sociocultural anthropology, subject, subject matter, society, positivism, values, mentality, methodology.

\section{Introduction}

Before taking a look at main schools of cultural studies we have to specify our perception of culturology as a scientific discipline. Culturology is one of the most problematic human sciences due to its complexity and interdisciplinarity of its main subject - culture as a phenomenon. On the one hand, it is apparently essential that various disciplines should carry out cultural studies.

(c) AesthetixMS 2016. This Open Access article is published under a Creative Commons Attribution Non-Commercial 4.0 International License (http://creativecommons.org/licenses/by-nc/4.o/), which permits non-commercial re-use, distribution, and reproduction in any medium, provided the original work is properly cited. For citation use the DOI. For commercial re-use, please contact editor@rupkatha.com. 
On the other hand, its subject cannot be confined to traditional research methods (accurate observation, measuring, experimental studies), so its ambiguity paves the way for numerous theoretical speculations "about culture". Such speculations strip cultural studies of necessary rigor of scientific approach and provide invalid universal inductions.

The challenge of defining culturology makes it reasonable to recall the definition of culturology articulated by Leslie White. He was the first to say that culturology is a scientific discipline. His well-known pioneer article on culturology has a very remarkable epigraph: "These specifically human peculiarities which differentiate the race of the homo sapiens from all other species of animals is comprehended in the name culture; therefore the science of specifically human activities may be most suitably called culturology" (Wilhelm Ostwald. Principles of the Theory of Education).

Thus, we obtain a methodological imperative, which can be defined as follows: it is necessary to study the main subject of culture - not as homo animals or homo faber like natural and engineering sciences study of biosystems, but as homo sapiens. Thereby White points out that various views on substance of science of culture (fields and systems of disciplines) advocated in academic discussions are based on very different and partially opposite moral and philosophical attitudes to the human. Traditional, objectivistic view offers only two approaches: studies focus either on rational mind, sensibility or - on its opposite - on the beastly nature, physiology, and pragmatics.

Given that the human belongs to sensible, spiritual reality Leslie White comes to an important conclusion: "But it is in the human species and here alone that we find understanding as a process of adjustment carried on by symbolic means". The human neuro-sensory-symbolic faculty affects beliefs of homo sapiens in course of philosophic cognition of the world. Leslie White says, that the driving force which determines human behavior is "extra-somatic factor of culture" rather than "organismic" motions, and comes to the conclusion which turns the page in independent evolution of cultural studies: behavior is a function of culture. This conclusion can be considered as another methodological imperative in the study of culture - it is the most productive to study culture not as a derivative of human efforts, behavior, activities, but as the basis of the latter as ideal norms, values and patterns generally accepted in a certain community, society, ethnic group, etc.

He adds that cultural determinism is opposed by philosophy of free will which is inherent to the West European thinking. The culture itself should be considered as "if it had an existence of its own independently of the human species". Thus White proposes ontological concept of culture. It is fundamental for the late culturology which studies "artificial" reality contrary to "natural" world.

Thereby one more methodological imperative for cultural studies is being formed culture as a transpersonal phenomenon has its own objective laws and internal logic that cannot be reduced to the laws of social life.

\section{Methods}

\section{Importance of the attitudes of $L$. White for the formation and development of culturology as a science}

At first this standpoint seems to be self-evident for Western cultural anthropology which lays claim to its principality in culture studies focusing on human sensibility and its faculties to create "second nature". Leslie White is critical towards such claims: the term "anthropology" signifies a 
great number of matters and has almost no meaning in cultural studies at all. It includes physical anthropology which in turn involves human paleontology, comparative morphology of apes, human genetics, physiology, psychology etc. Anthropology of culture refers to psychology, psychoanalysis, psychiatry, sociology, applied anthropology, history etc. (White). Hence this illusionary omnipotence of knowledge gained by cultural anthropology impairs all attempts to study culture which Western scholars fail to define as a self-consistent subject of research.

"Why should not a science of culture be culturology?" asks Leslie White comparing it to bacteriology, musicology and other sciences. He thinks that the way of culturology to status of self-consistent science was blocked both by those who championed free will philosophy, or cultural indeterminism, and by anthropocentrists who claimed to have discovered culture as second reality generated by the "natural" (virtually physiological) humans.

White did not identify culturologic knowledge to sociology as well, because sociology "assimilates culture to its basic concept of interaction, making culture an aspect, or a by-product, of the social process of interaction whereas the structures and processes of human society are functions of culture" (White).

In this way White assumes that culturology clearly shows "how, on the one hand, culture is an extra-somatic tradition that can be explained in terms of its own interactive elements and processes and how on the other hand, the individual organism is influenced" (White).

\section{Positions of national researchers on the nature of culturology as a scientific knowledge}

Interpretation of culturology failed to evade some terminological confusion which resulted in terminological and substantial ambiguities: 1) culturology is confused with cultural (or social) anthropology; 2) culturology is erratically equated to certain sections of historical science, first of all to study of customs and habits; 3) culturology is differentiated from cultural anthropology only by wider geographical range (it embraces both Western culture and world culture); 4) culturology is a purely Russian invention which is not recognized as a self-consistent discipline by Western scientists who promote cultural and social anthropology as a substitution. In fact they ignore validity of the term "culturology" which was introduced by its major legitimizer Leslie White to academic circles.

The forth case mentioned above is the most interesting for our discussions. It challenges the rationale of studying cultural phenomena neglected by Western anthropologists as unsubstantial for Western culture which are nevertheless essential to Russian culture and fundamental for cultural studies. To this end we should detect areas which are not studied by cultural (social) anthropology in the light of White's notion of culturology.

A rather holistic picture of what cultural (social) anthropology is from our perspective is offered in a very profound study "Sociocultural anthropology: history, theory and methodology. Encyclopedic dictionary" by the Russian state social institute (Sociocultural anthropology: history, theory and methodology. Encyclopedic dictionary, 2012).

Yury Resnik, one of the coauthors of this study, defines sociocultural anthropology as a compex of "scientific and academic disciplines which study human beings, human diversity in its typical forms and dimensions" (2012, p. 5). He adds that "self-realization, self-activity, unimpeded conscious self-development in human society and by human society are the main interests of an anthropologist" (2012, p.6). 
"Social and cultural anthropology... is a science of laws and premises of interaction between the human and his natural, social and cultural environment, which exposes its generic properties and group (communal) traits; it is a complex of scientific disciplines which study unity and diversity of forms of sociocultural existence of the the mankind" (Reznik, 2012. P. 345). The key feature of anthropology is its focus on essential models and mechanisms of social existence of people which show up in different types of cultures and societies (Reznik, 2012, p. 346).

Hence anthropology excludes culture from its subject field or considers it as some condition, environment etc., presuming that the human being is a substance which generates on its own some natural phenomena. Leslie White however cherishes culturological approach by which culture is a human-independent reality which impacts the human world.

Elna Orlova, the renowned Russian culturologist, attempts to give a holistic view of cultural anthropology and writes as follows: "Cultural anthropology is a wide field of social scientific knowledge based on idea that culture is generated and regenerated by humans as a result of active adjustment to changing natural and social environment. This cognitive area explores similarities and differences between culture by comparative analysis of its causes and results" (2012, p.11). The term "cultural anthropology" is used mainly in the USA. British (and sometimes American) social scientist talk about social anthropology, and in Germany and France it is known as ethnology. The term "ethnology" carries primordial connotations accentuating common origin of a group of people (ethnic group, nationality), while cultural (social) anthropology brings to the forefront the idea of social organization of people united by social interactions (social principle) and symbolic communication (cultural principle) (Orlova, 2012, p. 11).

Let us focus on some aspects of these definitions which are most significant for interpretation of culturology.

1. They neglect human dependence on culture and its influence on people. Culture is attributed a merely utilitarian role in human adjustment to environment.

2. Culture is predominantly considered in comparison to different cultures, mainly to its behaviors and artifacts which are assumed to ensure communal solidarity of human agents, their social interaction and efficient communication.

3. Such approach to cultural studies disregards cultural values, sacral and spiritual elements, culture is not viewed as any other self-consistent subject, which objective existence is recognized and thoroughly studied by scolars.

As evolution of Russian culturology showed, all elements of cultural phenomena mentioned in point 3 are what plays a pivotal role in further development of cultural studies. That means that dissent of many Russian social anthropologists against this approach is just a matter of principle. This explains the common fact that modern social anthropology denies ontology of cultural studies and refuses to consider culture an objective phenomenon. This context makes the following words of Elna Orlova more clear: "Society and culture are categories, concepts, but not a reality" (2012, p. 14) and "the term "Russia is the only country where spiritual culture" is used in its broad" (2012, p. 660). She believes that materialism and idealism are no more relevant for ontological orientation of the perceiving subject because they do not count for material or ideal origin of cultural reality" (2012, p. 66). Culture itself includes but "things", "samples of human relations", "symbolic units", its substance is just "matters of group living which contain nonheritable information and artificial, manmade artifacts" (Orlova, 2012. P. 663). 


\section{Results and investigation}

\section{Culturology and social and cultural anthropology}

As we leave spiritual and sacral senses out of culture, the approach sounds logical. Culture is a convenient tool for categorizing many "ex-cultural phenomena" and for studying human adjustment to environment (Xifra, 2012). However such standpoint on adjustment runs contrary to what Leslie White proposed: with neglect to spiritual and cultural aspects culture is viewed as a biological, purely pragmatic adjustment to purposes of physical survival. survival and existence in Russian culture have always been closely connected with question of life purposes which often lie beyond the boundaries of physical existence.

We deal with culturology of the other kind, which targets primarily at character features of human individuality which make homo sapiens unique and different form animals. Formally sociocultural anthropology complies with this criterion because it studies widely differing areas of human activity which have social and cultural impact. Thus academic schools in the USA and some other countries gave birth to cultural, linguistic, medical, biological, psychological, humanitarian, urban, Hispanic and visual anthropology (Orlova, 2012. P. 11 - 28). As for real substance of all these anthropologies this is not the case.

Elna Orlova believes that "functionalism, structuralism, culture and individuality (psychological anthropology)" are dominating in the modern sociocultural anthropology (Orlova, 2012, p. 18) and define its path: "functionalism primarily relates to the ways of social interaction and human relations, while structuralism in linguoanthropological sense studies social communication and its determinant signs and symbols" (Orlova, 2012. P. 20).

"Concept of culture and individuality provides that social community and its culture are a unitary whole system defined by realized forms of human relations with environment. Every culture selects and defines certain options of such relations which shape cultural patterns. People obtain cultural patterns in course of socialization and reproduce them in everyday life whereas they neglect other ways of establishing social ties" (Orlova, 2012. P. 21).

What has been said shows that anthropological studies have a strong behaviorist bias and melt into sociology and structural linguistics. They miss out on inner resources of cultural processes which influence spiritual self-expression, and no behavior or cultural patterns can close this gap in studies of individuality and society.

Elena Orlova is rather positive about White's contribution to cultural studies assuming that he reaffirmed significance of some evolutionary ideas (neoevolutionism): "This was a reaction on hyperprotection of cultural integrity and its regenerative potential and neglect to cultural changes. Leslie White played a pivotal role. He took classical ideas of evolutionism and renewed this theory with regard to modern sociological concepts bringing world cultural process to focus. He was the first to introduce principles of the general theory of systems into culturology as $\mathrm{T}$. Parson and E. Shils had done to sociology, and classified cultural system as a specific class of symbolic phenomena inherent exclusively to people. Leslie White rethought structuralist and functionalist approaches toward evolutionism and its methodological principles and described subject field of a science of culture named culturology" (Orlova, 2012, p. 21-22).

This detailed list of White's merits provided by Orlova has a smack of scientism and excludes values and attitudes from culturology. It assesses heritage of Leslie White, founder of culturology, in the same way constraining its tools to "general theory of systems" in cultural studies, study of symbols and structure-functionalist approach. Thus White's culturology 
interpreted by Orlova is deprived of values and attitudes and as a result of its subject turning into speculations about abstract notions and concepts.

We are not about to judge such assessment of White's culturology. It is more essential to outline research area designated for exploration of culturologists. If we use mainly scientific methods based on rational models and formalized languages, our studies will lose the very essence and diversity of cultural processes (Scherbakova et al., 2014). In this regard it suffices to say that many renowned Russian social and cultural scientists combined terms with metaphors, expression and rationality in their language style. This peculiarity makes up the "mental" core of the Russian culture which cannot be grasped with common models of European science. Comparison of its unique position among other cultures may give way to further evolution of modern culturology.

The outlook at the main traditions and paradigms in sociocultural anthropology given in the encyclopedic dictionary shows that it embraces a wide range of social and cultural problems though thorough study of mental structures which shape and drive cultural evolution are not its priority (McGrath, 2016). We will illustrate this idea with a closer analysis of some traditions and paradigms of sociocultural anthropology.

The first scientific area that emerged at the intersection of anthropology and culturology can be called behaviorism. Edward Thorndike (1874-1949) and John B. Watson (1878-1958) are its founders. Behaviorism is based on the idea of the importance of behavioral activity in the study of anthropological and cultural processes. Scientists are focused on behavior that can be observed and recorded as the material for further analysis. In modern science behaviorism is significant in pedagogy. Thus, in the US education system popular approaches are based on the ideas of behaviorism, which are used both to improve performance, discipline, attendance among all children and to include children with disabilities and socialization problems (e.g. children with autism spectrum disorders (ASDs)) in general education classes. In addition, ethology focusing on animal behavior is now actively studying behavioral activity.

The concept of diffusionism developed enough and proven by practical consideration should be noted. The concept has developed as a reaction to the theory of evolution, which, according to the founders of diffusionism, was to supplement the study of cultural processes from the standpoint of the evolutionary path of development of societies.

A number of scientific areas in cultural anthropology are closely related to the psychological aspects of human and culture existence. Cognitive anthropology is one of them. This scientific area is focused on the aspiration of scientists to understand and describe different cultures in terms of their creators, inhabitants of a particular territory, to have a look at the world through the eyes of a representative of another culture. For example, a cognitive anthropologist does not use the concepts and terminology of modern Western medicine in the description of behavior of another people and in his practices related to diseases and injuries as it would distort the picture of native medical concepts. Culture, as in the study of the worldview, is described from the inside, from the point of view of its representative.

"Psychological anthropology" is a scientific area similar to cognitive anthropology. We draw attention to the fact that psychological anthropology pays special attention to the study of "the collective unconscious", mental structures, which are largely a product of psychophysiological characteristics of certain subjects of culture and social communities.

A number of theories that make up socio-cultural anthropology, consider structural and functional characteristics of culture. Structuralism studies culture and society as a set of casual, 
universal structures underlying the observed phenomena. Researchers-structuralists pay particular attention to the study of underlying structures characterizing the mentality of society (Shapinskaya, 2012). If we take this characteristic of structuralism as a basis, non-conformity of its original orientation both with the study of "underlying" structures correlated with the "mentality" and the pre-emptive study of "observable phenomena" become obvious (Remizov, 2005). One often excludes the other or does not correspond to each other.

Functionalism that examines certain components of culture, society, which, according to the researchers, have certain functions and specific purpose in the system of functioning of cultural phenomena, can also be considered as a similar scientific area. Cultural phenomena are studied here from a perspective of the system approach, which allows to study the practicability of certain cultural norms and values for the functioning of an appropriate social system.

Postmodern concepts formed at the turn of the twentieth-twenty-first centuries should be also mentioned. Post-modernism is traditionally viewed as a continuation of and the opposition to modernism. Postmodernism is a special state of mind which, according to its adherents, occurs at the final stage of the existence of a particular culture. In this regard, postmodernism is a transhistorical phenomenon, it passes through different historical periods and it is impossible to separate it into a single or special time period (Mircea, 2014). In turn, a number of researchers defines postmodernism as a special era, which began with the emergence of post-industrial civilization (Grechko, 2012). The world of "perfect" in postmodernism is not viewed as an area of "transcendental", but as an area of "immanent" that is originally inherent in objective reality.

Interpretation of sociocultural anthropology proposed by Russian scholars engenders European positivist tradition which stands for "observable" subjects and for research phenomenon-based research methods. This approach excludes the very possibility of perceiving "transcendent" world, spiritual experience of humankind, which defined human image of homo sapiens. Attempts of sociocultural anthropologists to include range of problems culturology deals with into social context cannot complement cultural studies if they avoid researching spiritual and mental domain of cultural existence and maintenance (McGrath, 2016).

In this regard Leslie White writes: "As we have already shown, the assumption of the founders of sociology was far from adequate. True enough, a man behaves differently in the company of his fellows than when alone, just as roosters, dogs, ducks, and apes do. A sociology of man- or ape, rat, dog, or duck - is in order, therefore, in addition to a psychology. But to go no further would be to overlook a fundamental difference between man and all other species" (White, p. 427).

Psychological aspect of human studies in a greater degree involves penetration into inner life, inner feelings, thoughts and psychological patterns, than massive application of behaviorist models as it is typical for Western scholars. In psychological, mental context, the driving force of cultural studies is patterns of psychical living which define worldviews, ideas, values and attitudes - in a word, what is considered as ideal, what makes the world better and more beautiful, what distinguishes humans from animals and plants. This world is based on religiousness. It does not mean just religious identity. Religiousness is a distinguishing human trait, human desire to establish intrinsic relation to transcendent origin and to set moral attitudes towards self and society (Gunia et al., 2016).

No matter how sociocultural anthropologist give weight to religiousness in cultural evolution of people, they attribute this field of human existence to church matters and exclude religiousness out of range of problems of their researches (Gunia et al, 2016). In this case they 
leave arts and their history which involved religious stories, values and attitudes completely unexplored, they also often replace history of culture with history of arts regarding achievements of human culture from purely esthetic or economic prospective.

Moreover there is another issue in cultural studies which is very important for society and fundamental to sociocultural anthropology - how cultural image of an individual is shaped by values and attitudes and how they drive human and societal evolution in accordance with universal human values which are after all life goals. Refocusing of sociocultural anthropology implies refocusing of human researches on individual and communal problems which were traditionally associated with religious belief rather than knowledge. Unless refocusing of human studies spiritual life and its role in maintenance of human culture will be closed forever for our cognition.

\section{National researchers on prospects of culturological studies}

Russian sociocultural anthropologists saw this gap in conception of culture and of the human based on activism and sociological determinism and tried to complete their studies with references to culturology and to include these problems into research context of their works.

Olga Astafieva and Kirill Razlogov say that culturology is "an integrative discipline which emerged in late $19^{\text {th }}$ - early $20^{\text {th }}$ century as various teachings about culture and human beings had accumulated theoretical ideas about dynamics of cultural reality in time and space and summarized empirical studies and observations of culture and its functional, axiological and symbolic manifestations" (Astafieva, 2012. P. 606). Apparently this definition is very ambiguous. Further explanations of the two scholars do not make their understanding of scientific culturology less vague: "Culture is a system of norms and values regulating and defining social practices and synthesizing all forms of human activities rather than a particular case. Recognition of this fact defines the subject of scientific knowledge about culture, fixes its complexity and polysynthetism as well as sets key criteria for culturological knowledge which is integrative in its kind" (Astafieva, 2012. P. 611).

After all Olga Astafieva and Kirill Razlogov try to draw a distinction between sociocultural anthropology and culturology relying on a rather formal principle and to extend ubiquitous omnipotence claimed by anthropologists on culturology. All of a sudden culturology appears to embrace even a wider range of subjects than sociocultural anthropology.

"Sociocultural anthropology relies on sociology, psychology, ethnology whereas integrative capacities of culturology are much wider for they involve history, philosophy, history of arts, sociology, linguistics etc" (Astafieva, 2012. P. 612). In their opinion culturology admits prognostic studies, unlike anthropology. They go further and outline "basic integrative strategies of culturological studies which have its own subject priorities and are fundamental for modern culturology" (Astafieva, 2012. P. 613): theory of culture, historic and cultural analysis, applied studies (sociocultural practices, cultural policy), culturological discourse. Thus they claim that subject matter of culturology is wider and more divers than the one of social anthropology, whereas research areas of culturology are much narrower. Such speculations confuse the problem of culturological subject field even more.

Yuriy Reznik goes to the other extreme and tries to enlarge research area of culturology. He writes in his article "Culturology: projects of a general science of culture" that "the Western sociological thought suggested at least three projects of a general science of culture which have its 
anthropological basis in common. 1) culturology is a theoretic aspect of cultural anthropology which summarizes empirical outcomes of cultural studies (Leslie White) 2) culturology is an integrative science of culture based on scientific achievements of anthropology, sociology, psychology and other disciplines (James K. Faibleman); 3) culturology is an interpretive theory of culture (Clifford Geertz)" (Reznik, 2012, p. 616).

The term "culturology" did not find support abroad which was not the case in Russia. Yuriy Reznik writes that "culturology unified endeavors of philosophers, sociologists, ethnologists, linguists, art historians to diverge in two roads":

1) integration of disciplines which study culture, in other words a "summarizing term for sciences which study cultural behavior of individuals and communities on different stages of their historical existence (Vladimir Mezhuev, Elna Orlova) 2) system of knowledge about culture, or a knowledge area which combines potential and methods of social sciences, largely of sociology and cultural anthropology with human sciences, philosophy of culture and world arts (Gennadiy Drach et al.); 3) integrative field of cultural studies, "integrative expression of human knowledge", systematic summary of cultural studies (Pavel Gurevich); 4) integrative field of scientific knowledge” (Svetlana Levit)” (Reznik, p. 2012, p. $617-618)$.

Yuriy Reznik disagrees with this assumption and suggests his own vision of further scientific evolution of culturology. "It is notable that the most convincing interpretation of culturology is a project of science of culture which studies both "cross-cutting" and "integral" problems of functioning and evolution of this phenomenon. Its consistency consists in creation of a new theory (or theories) which summarize research outcomes and offer new hypotheses and concepts rather than a project of reorganization of the existing fields of knowledge into a new complex (configuration) of knowledge about culture. This is the only way it may take to find recognition among other sciences". (Reznik, 2012. P. 621)

Yuriy Reznik believes that for constructing such theory culturology needs to find its "own prospective of study". It may be "intrinsic" relations within the world of culture defined (and mediated) by sense" (Reznik, 2012. P. 625). This thesis sounds enigmatic, however it presumably implies that it is important to study deeper the sense of culture in its original traits which do not always find their way in artifacts or behavior patterns though they are reserved in the depths of human spirit.

In this regard it is reasonable to take a look at the extent this problems are reflected in Russian culturology which claims to be a self-consistent discipline and to decide whether it is right to associate culturology with spiritual human and societal problems.

In national cultural research culturology is usually divided into the following branches: theory of culture, cultural history, applied culturology. In various studies these branches may have different names, but the essence remains the same. The theory of culture (theoretical culturology) is a system of basic ideas concerning the emergence, existence and development of culture and its interaction with nature, man and society, approaches to its study, research methods. Let us draw attention to the fact that, as a rule, theoretical culturology is not defined as a scientific discipline, but it is only a system of basic ideas.

When studying the possibility of formation of culturology as an independent scientific branch, national scientists come to the conclusion that culturology does not have a subject, it is meaningless to distinguish a special spiritual culture, since culture is spiritual in nature and there 
is no need to distinguish a separate branch of knowledge to study the spirituality of culture (Belik, 2012).

It is worth noting that the critical attitude towards culturology is a consequence of underdevelopment of the subject and object of culturology in the national school. Researchers insisting on independence and formedness of a culturological paradigm are based on the assertion that a phenomenon of culture is based on the value characteristic. But the "world of values" has not become the main object of study in the current system of cultural sciences, including culturology, since in the study of culture still dominates the ideology of positivism eliminating the possibility of studying the value-mental area as a separate field of research.

Major works in the sphere of foreign cultural anthropology are devoted to the study of mentality and the phenomenon of "a soul of culture".

\section{Classic works of Spengler O. and a similar famous work of Danilevsky A.Y.}

At the present stage such scientific area as "cultural studies" is actively being included in the field of culturological research. It initially originated in Europe and is gradually penetrating into the minds of national researchers. In our opinion, this scientific area may be reconciled with the history of culture, but when studying the historical events through the projection of mentality, cultural memory (Frank, 1992).

The "world view", a set of ideas and images placed in the mental field and forming a kind of matrix of human perception of him/herself and the environment, takes an important place in the study of the cultural mental field (Nikolaev, 2012). Thus, the penetration into the mental reality is one of the most important possibilities to study current reality of human existence in its essential laws that are often inaccessible to direct observation. Recognition of this fact can be considered as a major prerequisite for the formation and development of culturology as a science.

\section{The study of national culture as one of resources of development of culturology as a science}

We confine ourselves to consideration of these publications as sufficiently indicative to determine the specificity of cultural knowledge by national cultural scholars, focused mainly on Western concepts of culture. Assuming that abroad cultural and social anthropology is the closest analogue of cultural studies, considering the fact that Western European and American science does not recognize culturology as an independent scientific discipline, theoretically there are the following options of prospects for its development in Russian conditions:

1. The majority of scholars abroad see no way for evolution of culturology as a science.

2. Culturology might evolve in a version of cultural and social anthropology no matter whether it has a status of a separate discipline or not.

3. Culturology might be recognized as a scientific discipline which has no parallels in cultural studies abroad.

\section{Conclusions}

The analysis of the state of modern culture reveals the following prospects for its development: 
1. The study of the spiritual content of culture as a certain invariant of cultural processes, preserving its essential characteristics in different historical periods, in different ethnic groups and societies, is a priority area for further cultural studies. This supra-historical content of culture can be identified through extensive studies of symbolic, mythological and religious components of culture on the basis of the search for universal dominants of cultural development of mankind, taking into account the diversity of cultural values of certain peoples and civilizations.

2. The main areas of cultural studies are as follows: cultural and anthropological studies focused on the spiritual world of a person and spiritual-moral reference points of social development, results of cultural sociology (especially the French and German school of cultural sociology studying the mentality, national character, the influence of culture on society), national and foreign traditions of spiritual and religious life, cultural and anthropological content of national and world art.

3. In this case there are real prerequisites for separation of those cultural universals and objective laws of culture functioning, which allow to overcome the existing Eurocentrism in cultural studies, as well as descriptiveness and subjectivism in the study of different cultures. The prevalence of the model of a subject of culture as "homo sapiens" can be "an assemblage point" and the integration of culturally significant facts, events, phenomena. This implies the actualization of axiological, spiritual and outlook reference points in society as cultureforming and culture-conforming factors of social development.

\section{References:}

O.N. Astafieva, K.E. Razlogov (2012) Kulturologiya: predmet I struktura [Culturology: subject and structure] // Sotsiokulturnaya antropologiya: Istoriya, teoriya i metodologiya: Enziklopedicheskiy slovar. Moscow. P. 6o6-615.

A.A. Belik (2012) Psikhologicheskaya antropologiya [Psychological anthropology] // Sotsiokulturnaya antropologiya: Istoriya, teoriya i metodologiya: Enziklopedicheskiy slovar. Moscow. P. 148-153.

A.A. Belik. (2012) Psichologicheskoye napravleniye (v sociokulturnoy antropologii [Psychological school (of sociocultural anthropology)] // Sotsiokulturnaya antropologiya: Istoriya, teoriya i metodologiya: Enziklopedicheskiy slovar. Moscow. P. 153-162.

A.A. Belik. (2012) Ekologicheskaya antropologiya [Environmental anthropology] // Sotsiokulturnaya antropologiya: Istoriya, teoriya i metodologiya: Enziklopedicheskiy slovar. Moscow. P. 209-221.

A.A. Belik. (2012) Etologiya kultury (etologiya cheloveka) [Ethology of culture (human ethology)] // Sotsiokulturnaya antropologiya: Istoriya, teoriya i metodologiya: Enziklopedicheskiy slovar. Moscow. P. 230 - 240.

P.K. Grechko. (2012) Postmodernism [Postmodernism] // Sotsiokulturnaya antropologiya: Istoriya, teoriya i metodologiya: Enziklopedicheskiy slovar. Moscow. P. 311-324.

V.G. Nikolaev. (2012) Biheviorism [Behaviorism] // Sotsiokulturnaya antropologiya: Istoriya, teoriya i metodologiya: Enziklopedicheskiy slovar. Moscow. P. 110-125.

V.G. Nikolaev. (2012) Funktsionalism [Functionalism] // Sotsiokulturnaya antropologiya: Istoriya, teoriya i metodologiya: Enziklopedicheskiy slovar. Moscow. P. 176-191. 
V.G. Nikolaev. (2012) Etnometodologiya [Ethnomethodology] // Sotsiokulturnaya antropologiya: Istoriya, teoriya i metodologiya: Enziklopedicheskiy slovar. Moscow. P. 221-230.

E.A. Orlova (2012) Diffuzionism i kulturnaya diffuziya [Diffusionism and cultural diffusion] // Sotsiokulturnaya antropologiya: Istoriya, teoriya i metodologiya: Enziklopedicheskiy slovar. Moscow. P. 125-132.

E.A. Orlova. (2012) Kognitivnaya antropologiya [Cognitive anthropology] // Sotsiokulturnaya antropologiya: Istoriya, teoriya i metodologiya: Enziklopedicheskiy slovar. Moscow. P. 132-140.

E.A. Orlova. (2012) Kultura: osnovaniya, opredeleniya, poniyatiya [Culture: foundations, definitions, notions] // Sotsiokulturnaya antropologiya: Istoriya, teoriya i metodologiya: Enziklopedicheskiy slovar. Moscow. P. 659-676.

E.A. Orlova. (2012) Kulturnaya (sotsialnaya) antropologiya [Cultural (social) anthropology] // Sotsiokulturnaya antropologiya: Istoriya, teoriya i metodologiya: Enziklopedicheskiy slovar. Moscow. P. 11-28.

E.A. Orlova. (2012) Evolutsionism [Evolutionism] // Sotsiokulturnaya antropologiya: Istoriya, teoriya i metodologiya: Enziklopedicheskiy slovar. Moscow. P. 191-209.

Yu.M Reznik. (2012) Kulturnaya (sotsialnaya) antropologiya: predmet i teoreticheskiye osnovaniya [Cultural (social) anthropology: subject matter and theoretical foundations]// Sotsiokulturnaya antropologiya: Istoriya, teoriya i metodologiya: Enziklopedicheskiy slovar. Moscow. P. 345-362.

Yu. M. Reznik. (2012). Kulturologiya: proyekty obschey nauki o culture [Culturology: projects of general science of culture] // Sotsiokulturnaya antropologiya: Istoriya, teoriya i metodologiya: Enziklopedicheskiy slovar. Moscow. P. 615-627.

Yu.M. Reznik (2012). Specifika antropologicheskogo podkhoda k izucheniyu obschestva i kultury [Specifics of anthropological approach to societal and cultural studies] // Sotsiokulturnaya antropologiya: Istoriya, teoriya i metodologiya: Enziklopedicheskiy slovar. Moscow. P. 5-8.

Remizov V.A. Social ecology of personal culture. - Moscow: MGUKI, 2005. - 163 p.

Sotsiokulturnaya antropologiya: Istoriya, teoriya i metodologiya: Enziklopedicheskiy slovar [Sociocultural anthropology: history, theory and . Moscow. $1000 \mathrm{p}$.

Frank S.L. Spiritual foundations of society. - Moscow: Publishing House "Republic", 1992. - 511 p. - (The thinkers of the twentieth century).

Leslie White. (2004). Selected works. Science of culture. Moscow, 2004. 960 p.

E.N. Shapinskaya. (2012). Strukturalism [Structuralism] // Sotsiokulturnaya antropologiya: Istoriya, teoriya I metodologiya: Enziklopedicheskiy slovar. Moscow. P. 168-176.

Gunia, B., Brett, J., Gelfand, M. (2016) The science of culture and negotiation. Current Opinion in Psychology, 8, 78-83. http://doi:10.1016/j.copsyc.2015.10.008.

McGrath, L. (2016) Self-mentions in anthropology and history research articles: Variation between and within disciplines. Journal of English for Academic Purposes, 21, 2016, 86-98. http://doi:10.1016/j.sbspro.2014.05.270.

Mircea A. D. (2014) Truth and Knowledge in Postmodernism. Procedia - Social and Behavioral Sciences. Volume 137, 9 July 2014, Pages 165-169. http://doi:10.1016/j.sbspro.2014.05.270.

Scherbakova, A.I., Kamenets, A.V., Zinchenko, E.O. (2014). Potential of Musical and Pedagogical Analysis of Socio-cultural Interaction Processes. Asian Social Science. - Vol. 10, 24: 140-150 pp.

Xifra, J. (2012) Public relations anthropologies: French theory, anthropology of morality and ethnographic practices. Public Relations Review. 38 (4), 2012. 565-573. http://doi:10.1016/j.pubrev.2012.05.003. 